\title{
sciendo
}

\section{RETROSPECTIVE ANALYSIS OF LAND USE LAND COVER DYNAMICS USING GIS AND REMOTE SENSING IN CENTRAL HIGHLANDS OF ETHIOPIA}

\author{
MAMMO SIRAJ $^{1,2^{*}}$, KeBIN ZHANG $^{1}$, KIDANE MOGES $^{3}$ \\ ${ }^{I}$ Beijing Forestry University School of Soil and Water Conservation, Beijing Forestry \\ University, Beijing 100083, China. \\ ${ }^{2}$ Department of Biology, College of Natural Science, Ambo University, Ambo, Ethiopia. \\ ${ }^{3}$ Department of Natural Resource Management, College of Agriculture and Veterinary \\ Science, Ambo University, Ambo, Ethiopia. \\ *Corresponding author e-mail: sirajmammo@gmail.com
}

Received: $4^{\text {th }}$ May 2017 , Accepted: $31^{\text {th }}$ July 2018

\begin{abstract}
Assessing and quantifying the current forest resources status underpins sustainable forest resources planning and management. To this end, this study was conducted to analyze the dynamics of land use cover change (LUCC) and explore their drivers at the central highlands of Dry Afromontane Chilimo-Gaji forest for the study period (1973-2015) under consideration. The result of the study indicated that landscape trends have occurred in Chilimo-Gaji forest over the last 43 years and five classes of LUCC namely shrub land, rural settlement, bare land and road, forest land and agricultural land were identified. The most commonly reported drivers of deforestation in the study area were expansion of agricultural land, rural settlements, population growth, insecurity of the tenure and rights over the land, timber production and fuel wood collection. Surprisingly, the increasing demand for agricultural land and human settlement for increasing human population underpinned by expansion of agricultural activities led to the clearing of forest land in the study area. The study reveals that the forest land cover type has lost 922.14 hectares $(26.96 \%)$ which were changed into other land cover types such as agriculture and settlement for the study period under consideration with an annually rate of 21.45 ha. However, deforestation rates showed declining trend between the time periods 2008-2015 as a result of introduction of Participatory Forest Management (PFM) schemes (1996) which involve the local community in management and sharing of the benefit obtained from the management. In order to promote sustainable forest resources management in the study area in the years to come, integrated land use planning and management and addressing key drivers of deforestation were recommended.
\end{abstract}

Keywords: Chilimo-Gaji, Land Use Land Cover, Oromia, Participatory Forest Management, Retrospective

\section{INTRODUCTION}

Forest resources are the most significant material basis of countrywide sustainable development and periodical monitoring of the status and change of forest resources with the 
Siraj M., Zhang K., Moges K.: Retrospective Analysis of Land Use Land Cover Dynamics Using GIS and Remote sensing in Central Highlands of Ethiopia

help of remote sensing (RS) and geographic information system (GIS) underpins sustainable utilization of forests and its renewal (Boyd \& Danson, 2005; Desclée et al, 2006; Agarwal et al, 2010). To this end, land use mapping is important for evaluation, management and conservation of natural resources of an area and the knowledge on the existing land use is one of the prime prerequisites for suggesting better use of land (Golmehr, 2009). In other words, understanding the dynamics of land-use and land cover has increasingly been acknowledged as one of the vital research imperatives in global environmental change research (Geist, 1999; Lambin et al., 2001; Geist \& Lambin, 2001; Jahjah \& Ulivieri, 2004) and assessing and figuring the current forest resources status is claimed as a precondition for sustainable forest resources planning and management (Mekonnen et al, 2016).

Changes in land use are mostly attributed to human actions resulting in high negative effects on ecosystem functioning and biodiversity (Zornoza et al, 2015). To study the land use land cover changes, the application of remotely sensed data is important as it takes in less time, low cost, and with better accuracy in association with Geographical Information System that provide suitable stand for data analysis, update and retrieval (Agarwal et al, 2010). Moreover, remotely sensed data are useful for mapping and monitoring vegetation, and LUCC (Vashum \& Jayakumar, 2012).Generally, remote sensing and GIS based change detection studies have primarily focused on providing the knowledge of how much, where, what type of LUCC has happened (Running \& Bauer, 1996; Weng, 2001, Foody, 2002; Chowdhury, 2006; Alemayehu et al, 2009).

LUCC has increasingly become a key research priority for national and international research programs examining global natural resources and environmental change (IGU, 1998; Pielke et al, 2002; Du et al, 2014; Biru \& Debay, 2015). For instance, LUCC dynamics influences many aspects of the natural environment (Garede \& Minale, 2014). In order to study biodiversity conservation, ecosystem assessment, and climate change and to model environmental changes, up-to-date global land-cover data sets are exceedingly important (Giri et al, 2007; Keno \& Suryabhagavan, 2014). Moreover, historical LUCC patterns are a means to assess the multifaceted drivers and responses in order to enhance project forthcoming trends of human activities and LUCC (Ramankutty \& Foley, 1998; Alemayehu et al, 2009). Land cover has been claimed to go under constant changes with interaction of human beings and resulted in modification of ecosystem and its services. Concerns about LUCC have been emerged in the research agenda on global environmental change several decades ago with the recognition that land surface processes impact climate (Morshed, 2002; Lambin et al, 2003).

The most important drivers of landscape modification are associated with social and economic factors (Turner et al, 1996) which results in habitat loss and degradation underpinning impaired ecosystem functions and reduced ecosystem services (Gillanders et al, 2008) and global environmental change (Skole et al., 1997).

Land resource is the hub for the implicit or explicit tie between the rural community and the state (Zerga, 2016). Land covers dynamics particularly deforestation has become a global concern, with dramatic implications for human livelihood systems (Bewket, 2002). Land use conversion due to increasing human and livestock population is a common experience in protected areas of most Eastern African countries like Ethiopia (Pomeroy et al, 2003). In other words, LUCC through inappropriate agricultural practices and high human and livestock population pressure have led to severe land degradation in the Ethiopian highlands (Alemu, 2015). There were some local studies on land cover and land use changes in Ethiopia. However, the available local level land cover and land use change 
studies (Amare, 2007; Haregeweyn et al, 2012) were dominantly undertaken in the northern part of the country (Gessesse \& Kleman, 2007) and such studies are scant in other parts of Ethiopia. Hence, this study analyzed the dynamics of land use and land cover changes and explored their drivers for the study area with the aim of contributing for sustainable natural resources planning and management for the study area and Western Shoa Zone of Oromia Regional State, Ethiopia.

\section{MATERIALS AND METHODS}

\section{The Study Area}

Chilimo forest is one of the few remnant native dry Afro-Montaneforests on the Central Highlands of Ethiopia located in the Dendi district near to the small town of Ginchi, Western Shewa Zone, Oromia State of Ethiopia. Its geographical location is $38^{\circ} 10^{\prime} \mathrm{E}$, and $9^{\circ} 05 \mathrm{~N}$. Altitudinally, the forest area ranges between 2170 to $3054 \mathrm{~m}$ a.s.l. The forest is a small enclave in the western section of the ridge that stretches from the capital westward to Gedo highlands (Soromessa \& Kelbessa, 2014). It's home to over 150 bird species, 21 mammal species and several predictive subspecies such as the Menelik's bushbuck, vervet monkey, Colobus monkey, Anubis baboon and Leopard (Woldemariam, 1998). The forest is composed of mixed broad leaved coniferous forest and characterized by the dominant tree species of Juniperusprocera, Podocarpus falcatus, Prunusafricanum, Oleaeuropaea, and Hageniaabyssinica.The report from Soromessa \& Kelbessa (2014) indicated that Chilimo- Gaji forest is known with its diversity and endemism with a total of 213 different plant species categorized into 83 families, with angiosperm 193 species, pteridophytes (16 species) gymnosperms (represented by 2 exotic and 2 indigenous species); including 17 plant species that are unique to the Chilimo-Gaji forest.

Chilimo forest is categorized as one of Ethiopia's 58 national priority forest protected areas in order to minimize deforestation. Due to continuous deforestation, the Chilimo forest cover has declined from 22,000 ha in 1982 to 6000 ha in 1991 (Dugo, 2009). The forest cover area is estimated about 5,000 ha, owned by the state. Though the forest is owned by state, currently it is divided in to blocks and managed by forest user groups and cooperatives under the PFM arrangement schemes. This type of forest management in many regions is assumed to be acting to improve forest conditions and the livelihood of the forest user groups.

Chilimo is the pioneer of PFM site in Ethiopia, where the forest user groups have formed a strong cooperative union. Forest is important to the local people for grazing, firewood, as source of water, and construction materials. PFM focuses on improving the livelihood and conserving natural forest systems through local participation and cooperation. PFM can deliver multiple outcomes such as carbon storage, livelihood benefits and biodiversity conservation (Agrawal \& Angelsen, 2009) and can lead to sustainable use of forest resources. 
Fig. 1: Map of the study area

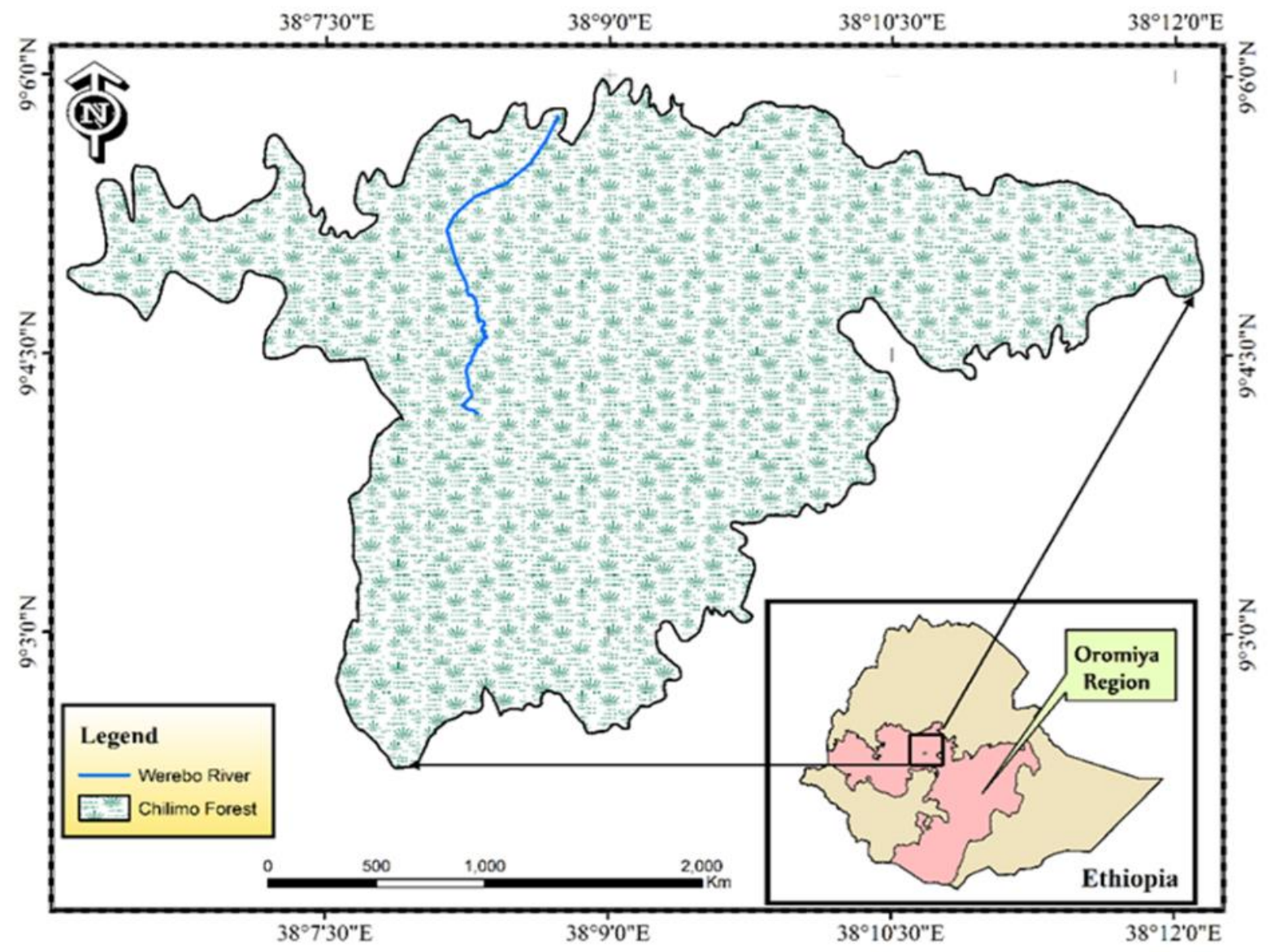




\section{Data Sources and AcquisitionMethod}

Satellite Remote sensing play a crucial role in determining, enhancing and monitoring the overall landscape change worldwide spatial and temporal.To study trends of LUCC dynamics total of 5 land satellite images for the past 43 years were downloaded from http://earthexplorer.usgs.gov where freely available (Table 1), to assess forest cover changes during the study periods. The images were downloaded during the dry season of the year because they are more likely to be cloud free and their spectral properties are less affected by the availability of moisture. Ground truthing exercise was carried out in Chilimo-Gaji forest in which the different land use/cover types existing with the aid of global positioning system (GPS).The data for the drivers of the change were collected from 140 household heads through interviews.

Table 1: Description of remote sensing data

\begin{tabular}{|c|c|c|c|c|c|}
\hline $\begin{array}{l}\text { Sensors } \\
\text { Study }\end{array}$ & $\begin{array}{l}\text { Path and } \\
\text { Row }\end{array}$ & $\begin{array}{l}\text { Spectral } \\
\text { Bands }\end{array}$ & $\begin{array}{l}\text { Pixel Size } \\
(\mathrm{m})\end{array}$ & $\begin{array}{l}\text { Date of } \\
\text { Acquisition }\end{array}$ & Source \\
\hline 1973 & $181 / 54$ & 4 bands & $\begin{array}{l}\text { Resampled } \\
\text { to } 30 * 30\end{array}$ & $01 / 31 / 1973$ & USGS \\
\hline 1984 & $169 / 54$ & 7 bands & $30 * 30$ & 02/25/1984 & USGS \\
\hline 1998 & $169 / 54$ & 7 bands & $30 * 30$ & 01/26/1998 & USGS \\
\hline 2008 & $169 / 54$ & 8 bands & $30 * 30$ & $01 / 01 / 2008$ & USGS \\
\hline 2015 & $169 / 54$ & 9 bands & $30 * 30$ & $01 / 29 / 2015$ & USGS \\
\hline
\end{tabular}

\section{Image pre-processing}

Raw satellite images were affected by systematic and random errors and will not be directly utilized for features identification and any applications and it needs some correction (Ayele, 2011) and need to remove the errors. Therefore standard image processing techniques of extraction, layer stacking, radiometric Correction, geometric correction/ georeferencing and change detection were performed on the 5 Landsat images downloaded and obtained on different dates and years of of dry season in the study area. The satellite images was orthorectified to a Universal Transverse Mercator projection using datum WGS (World Geodetic System) 84 zone 37N, and image of 1973 is resample from 57 by 57 cell size to 30 by 30 cell size.

\section{Remote Sensing Data Analysis}

In image analysis, ground reference data play important role to determine information classes, interpret decisions, and assess accuracies of the results (Thapa \& Murayama, 2009). The data obtained from the fieldwork was used for validating land-use/cover interpretation from satellite image, for image classification and for qualitative description of the characteristics of each land use/ cover class. The software ERDAS imagine 14.1 and Arc GIS 10.1 were employed for satellite image processing and LUCC change analysis as represented diagrammatical in the figure (Fig. 3.).

Image classification is defined as the extraction of differentiated classes or theme categories from raw remotely sensed digital data(Ismail \& Jusoff, 2008) and creating thematic maps from satellite images (Golmehr, 2009), in which all pixels in an image automatically categorize into land cover classes. Landsat satellite images for 1973, 1984, 1998, 2008 and 2015 with path 169 and row 54 (169/54) were downloaded and used to analyze temporal changes. And using supervised classification five LUCC types; shrub 
Siraj M., Zhang K., Moges K.: Retrospective Analysis of Land Use Land Cover Dynamics Using GIS and Remote sensing in Central Highlands of Ethiopia

land, rural settlement, bare land and roads, agricultural land and forest land were identified for the study area for the period 1973-2015.

In order to clearly identify the type and size of LU/LC in the study area from the multi spectral and temporal satellite images, a reconnaissance survey was carried out in January 2015 to acquire general understanding of the land pattern. The reconnaissance survey is assisted by information's collected from the key informants past, present knowledge coupled with interpretation of remote and interpretation of remotely sensed satellite image. Finally, five classified maps were developed corresponding to 1973, 1984, 1994, 2008 and 2015. Each satellite images were classified into five LUCC classes using supervised image classification coupled with the maximum likelihood classification algorithm. Ground truth data collection was carried out for collecting the absolute location of different land uses to use them as training sites during classification and for accuracy assessment of the classified land cover land use map of 2015 classification year. A total of 250 GCP's were collected randomly from the study area considering area proportion for different LUCC classes.

ERDAS Imagine software algorisms were used to perform classification and post classification comparison of change detection which involves the application of multi-temporal datasets to analyze the changes between consecutive classification years. It is the process of sorting pixels into a finite number of individual classes, or categories of data, based on their data file values (Rogana \& Chen, 2004). Matrix analysis produces a thematic layer that contains a separate class for every coincidence of classes in two layers and the output is best described with a matrix diagram (ERDAS Field Guide, 1999). The classes of the two input layers represent the rows and columns of the matrix. The output classes are assigned according to the coincidence of any two input classes.

\section{Accuracy Assessment}

The accuracy assessment measures how many ground truth pixels were classified correctly. Accurate information on land use land cover changes and the forces and processes behind is essential for designing sound environmental policies and management (Minale, 2013). Accuracy assessment is very important for understanding the classification results and employing these results for decision-making (Lu et al, 2003).In this study, the classification accuracy for recent LUCC map was carried out using ground control points from field observations as the major sources of reference data and set of reference points. These GCP were collected in same dry season to remove any sort of discrepancy in vegetation reflectance behavior. According to Jensen 2003, producer accuracy gives how well a certain area can be classified. The result of an accuracy assessment delivers us with an overall accuracy of the map based on an average of the accuracies for each class in the map (Ayele, 2011).The accuracy assessment was made, and it result $95.89 \%$ for forest land and $86.49 \%$ agricultural land (Table 2). The users' accuracy that was the percentage of correctly classified from total classified shown $100 \%$ for rural settlements and $91.43 \%$ for agricultural lands LUCC. The overall classification accuracy was $88.00 \%$ and the overall kappa statistics was 0.82 there is $82 \%$ better agreement than by chance alone. According to Monserud (2002), the scientifically accepted result for kappa statistics was defined as poor when kappa coefficient is less than 0.4; good when it was between 0.4 and 0.7 and it will be taken as excellent when kappa coefficient is greater than 0.75 . Therefore this finding shows that there is a strong agreement between the classification map and the ground reference information indicating kappa coefficient ranges of all the LUCC classes were excellent, (Fig. 2). The accuracy level of each land cover category was given in (Table 2). 
Table 2: The accuracy level of each land-cover category

\begin{tabular}{ccccccc}
\hline S. N & $\begin{array}{c}\text { LUCC } \\
\text { Class } \\
\text { Name }\end{array}$ & $\begin{array}{c}\text { Reference } \\
\text { Totals }\end{array}$ & $\begin{array}{c}\text { Classified } \\
\text { Totals }\end{array}$ & $\begin{array}{c}\text { Number } \\
\text { Correct }\end{array}$ & $\begin{array}{c}\text { Producers } \\
\text { Accuracy }\end{array}$ & $\begin{array}{c}\text { Users } \\
\text { Accuracy }\end{array}$ \\
\hline 1 & AL & 37 & 35 & 32 & $86.49 \%$ & $91.43 \%$ \\
2 & Bl & 10 & 10 & 8 & $80.00 \%$ & $80.00 \%$ \\
3 & FL & 73 & 79 & 70 & $95.89 \%$ & $88.61 \%$ \\
4 & RSL & 5 & 2 & 2 & $40.00 \%$ & $100.00 \%$ \\
5 & ShL & 25 & 24 & 20 & $80.00 \%$ & $83.33 \%$ \\
\hline & Totals & 150 & 150 & 132 & & \\
\hline
\end{tabular}

Fig. 2: Conditional kappa coefficient for each LUCC Category

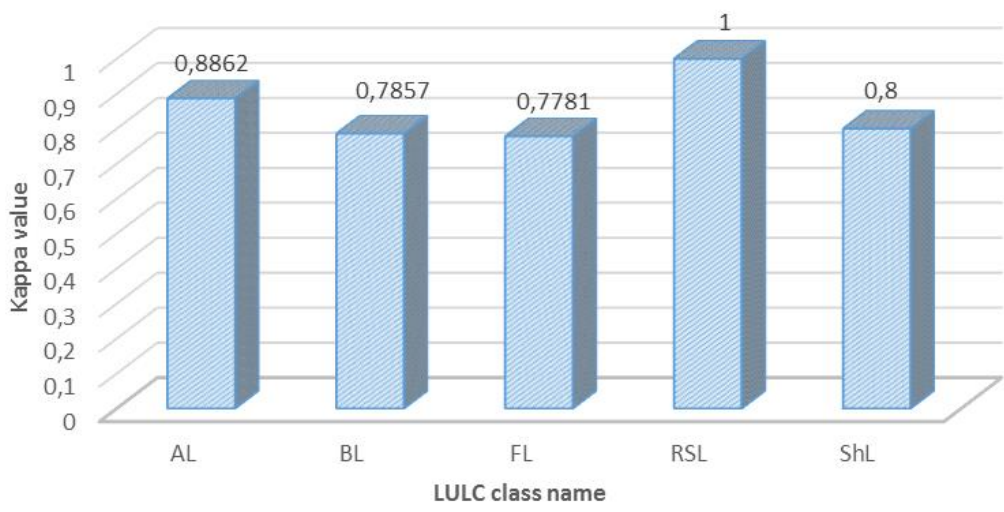

*Al=Agricultural land, $\mathrm{BL}=$ bare land and road, $\mathrm{FL}=$ Forest land, $\mathrm{RSl}=$ Rural Settlements, $\mathrm{Sh}=$ Shrub lands

\section{Change Detection}

The accuracy of change detection on the earth's surface is important for understanding the relationships and interactions between human and natural phenomena (Alqurashi \& Kumar, 2013). LUCC detection is necessary for updating land cover maps and the management of natural resources. Post classification comparison was computed to create LUCC trend matrix using ERDAS 14 and ArcGIS10.1 for 1973, 1984, 1998, 2008 and 2015 land cover classification maps. Areas that are converted from each class to any of the other classes were computed and the change directions were also determined. Areas that are converted from each class to any of the other classes were computed and the change directions were also determined.

The rate of land-use/land-cover change for each class was calculated as

Rate of change (ha/year $=\frac{\mathbf{R}-\mathbf{P}}{\mathbf{Y}}$. Where: $\mathrm{R}=$ Recent area of LUCC in ha, $\mathrm{P}=$ Previous area of LUCC in ha, $\mathrm{Y}=$ interval between $\mathrm{R}$ and $\mathrm{P}$ in years.

Kappa: Estimated as ( $\breve{\mathrm{K}})$.Kappa is used to measure the agreement or accuracy between the remote sensing derived classifications maps (Jensen, 2003). It reflects the difference 
Siraj M., Zhang K., Moges K.: Retrospective Analysis of Land Use Land Cover Dynamics Using GIS and Remote sensing in Central Highlands of Ethiopia

between actual agreement and the agreement expected by chance (Keno \& Suryabhagavan, 2014).

$$
\text { Kappa }=\frac{\text { observed accuracy }- \text { chance agreement }}{1-\text { Chance agreement }}
$$

- Observed accuracy determined by diagonal in error matrix.

- Chance agreement incorporates off-diagonal

$$
\text { Overall accuracy }=\frac{\text { number of pixels correctly classified }}{\text { total number of pixels }}
$$

For example Kappa of 0.722 means there is $72.2 \%$ better agreement than by chance alone.

\section{RESULT AND DISCUSSION}

\section{LUCC Classes of the Study Area}

To understand the changes occurring within a period of time an approach of temporal analysis for change detection was carried out. The LUCC maps of the Chilimo-Gaji Forest for five reference years and statistical summaries of the different LUCC types were presented (Fig. 3. and Fig. 4.). LUCC results were obtained by using combined methods of remote sensing and GIS techniques from Landsat images of 1973, 1984, 1998, 2008 and 2015 and have indicated that the Chilimo-Gaji forest was subject to considerable land use changes. During these study period years, the forest land area has been degraded, though, the forest has shown some improvement after the introduction of PFM to the study area specifically from 2008-2015 at the annual rate of 0.15 (Table 5).

In the present study, five classes of LUCC have presented namely shrubland, rural settlement, bare land and road, forestland and agricultural land were classified (Table 3 ). The LUCC dynamics are discussed in the subsequent sections.

Table 3: LUCC and their description

\begin{tabular}{lll}
\hline S.N & LUCC class & LUCC Description \\
\hline 1 & Shrub Land & $\begin{array}{l}\text { Land covered by scattered small trees ( } 15 \mathrm{~m} \text { in height), bushes, } \\
\text { shrubs and mixed with grass vegetation } \\
\text { Areas composed of small villages and/or scattered hamlets; } \\
\text { mostly located at the center of the forest s or at the foot of the } \\
\text { forest }\end{array}$ \\
2 & Rural Settlement & $\begin{array}{l}\text { Exposed stone, sand and soil or Non vegetated area dominated } \\
\text { by rock out crops, roads, eroded and degraded lands }\end{array}$ \\
3 & Bare Land and road & $\begin{array}{l}\text { Land covered with dense trees which includes ever green forest } \\
\text { land, mixed forest and plantation forests. } \\
\text { Areas of land ploughed/prepared for growing rain fed or } \\
\text { irrigated }\end{array}$ \\
\hline
\end{tabular}


Journal of Landscape Ecology (2018), Vol: 11 / No. 2

Fig. 3: Map of Land use and cover changes in Chilimo-Gaji forest 1973-2015
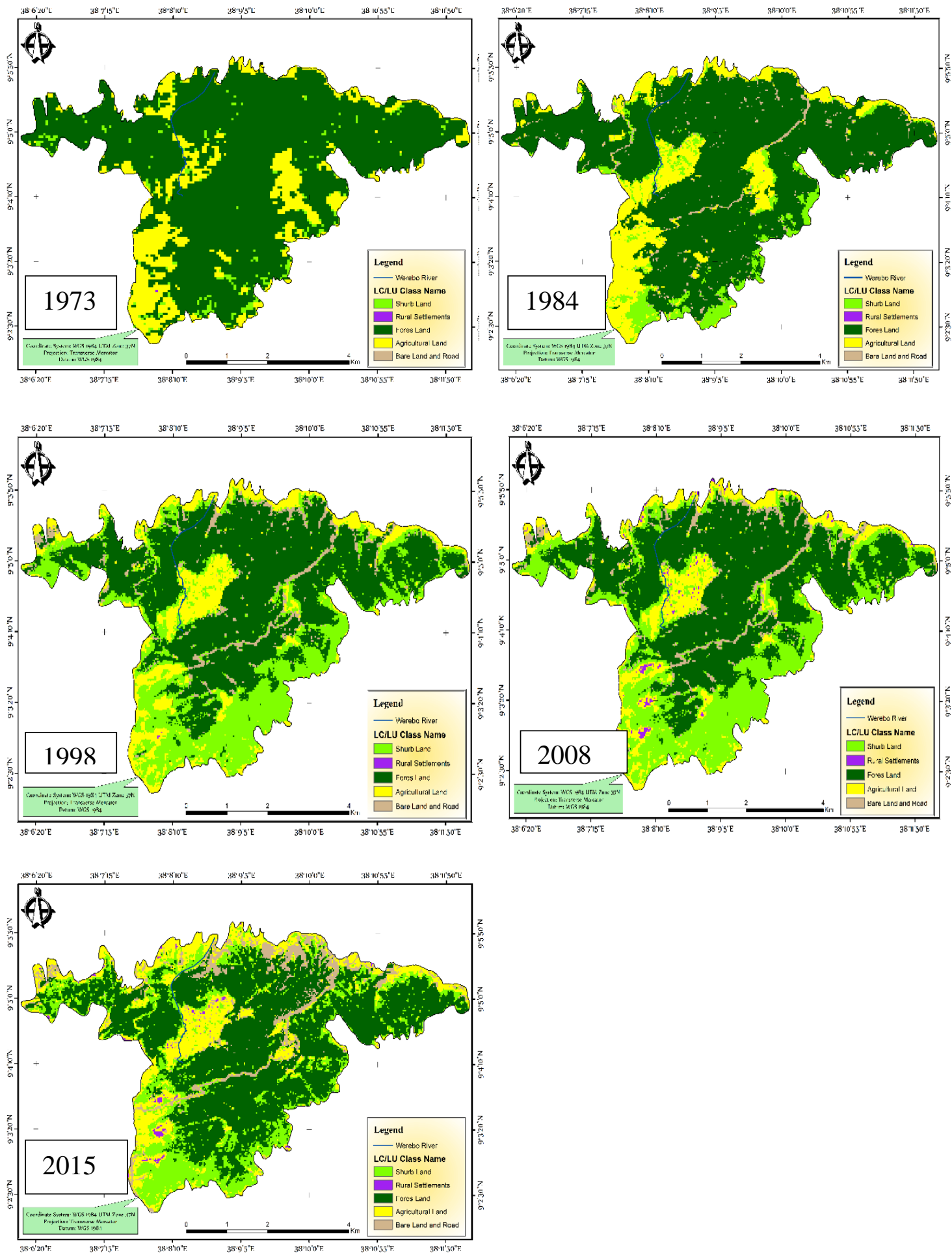
Siraj M., Zhang K., Moges K.: Retrospective Analysis of Land Use Land Cover Dynamics Using GIS and Remote sensing in Central Highlands of Ethiopia

Fig. 4: LUCC classes in the Study Area from 1973-2015

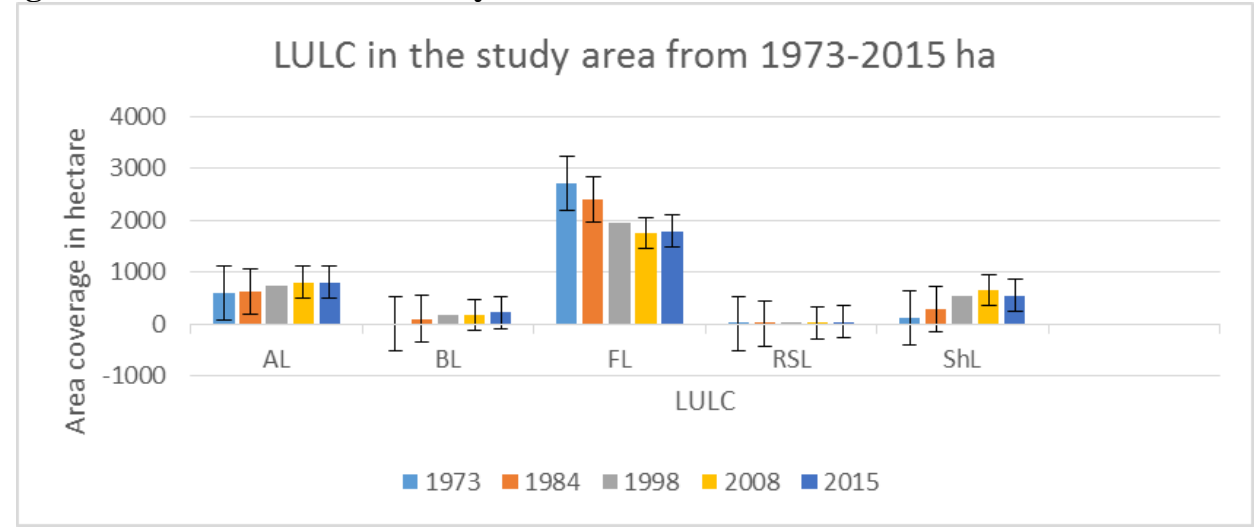

Shrubland (ShL). Land covered by ShL in the Chilimo Gaji forest was 118.44 ha, accounting for $3.46 \%$ of the total area in 1973 . The land cover share of shrubland has been continuously increasing by $8.46 \%, 16.31 \%, 19.10 \%, \%$ respectively. However, in 2015, it showed a decrease of $3 \%$ and become $16.10 \%$, on the indicated years (Table 4). During the study time, about 432.27 ha of area land were gained from other land use cover. There was more than three-fold increase from 1973 to 2015 which had changed the cover from $3.46 \%$ to $16.10 \%$ within the last 43 years. This study has indicated the increment of shrubland on the expense of mostly forest land.

Rural Settlements (RSL). During the entire period of study, the area under rural settlement land has increased persistently from 0.36 ha $(0.01 \%)$ in 1973 to 50.43 ha $(1.47 \%)$ in 2015 . The land cover share of rural settlements land has been continuously increasing by $0.071 \%, 0.469 \%, 0.55439 \%, 2.703662 \%$ respectively, for the indicated years (Table 4 and Fig. 5.). The trends showed a consistent expansion of settlement LUCC over the four decades being analyzed from (1973-2015). The rural settlement has expanded mostly at the expense of forest land implying the presence of deforestation in the study area.

Bare Land and road (BL) in 1973 there was no land covered with bare land and road in Chilimo-Gaji forest. However, the bare land has appeared in 1984 as seen in (Table 4) with a coverage 104.01 ha. After 1984 the coverage of bare land has continuously increased respectively, for the indicated periods (Table 4). This has affected the forest coverage of the study area during the study periods. The road from Ginchi to Jeldu is expanded at the expense of forest landand it makes the forest accessible to firewood collection, timber production and charcoal. 
Table 4: LUCC (1973-2015) in Chilimo Gaji Forest

\begin{tabular}{llllllllllll}
\hline S.N & LUCC & $\begin{array}{l}1973 \\
\text { ha }\end{array}$ & $\%$ & ha & $\%$ & ha & $\%$ & ha & $\%$ & ha & $\%$ \\
\cline { 2 - 10 } 1 & AL & 590.5 & 17.25 & 627.66 & 18.35 & 735.5 & 21.5 & 810.48 & 23.7 & 804.87 & 23.53 \\
2 & BL & 0 & 0 & 104.01 & 3.04 & 165.9 & 4.85 & 180.63 & 5.28 & 224.97 & 6.58 \\
3 & FL & 2712 & 79.28 & 2397.96 & 70.11 & 1959.2 & 57.28 & 1748.66 & 51.1 & 1789.38 & 52.32 \\
4 & RSL & 0.36 & 0.01 & 1.47 & 0.04 & 1.86 & 0.05 & 27.18 & 0.79 & 50.43 & 1.47 \\
5 & ShL & 118.4 & 3.46 & 289.26 & 8.46 & 557.87 & 16.31 & 653.41 & 19.1 & 550.71 & 16.1 \\
& Total & 3420 & 100 & 3420.36 & 100 & 3420.4 & 100 & 3420.36 & 100 & 3420.36 & 100 \\
\hline
\end{tabular}

*Al=Agricultural land, $\mathrm{BL}=$ bare land and road, $\mathrm{FL}=$ Forest land, $\mathrm{RSl}=$ Rural Settlements, $\mathrm{Sh}=$ Shrub lands

Forest Land (FL) was the first largest LUCC class type land cover, with the share of 2711.52 ha $(79.28 \%)$ of the total area of the study area in 1973 (Table 5 see in appendix). Forest cover has shown a rapid decrease during the entire study period. The land cover share of the forest has declined to $70.11 \%, 57.28 \%$, and $51.13 \%$ in 1984, 1998, 2008 respectively. This has shown that deforestation rate in the study area was rapid and the majority of available forests have changed into other land use units. However, it slightly increased in the remaining study years because of conservation practice implemented in the area by the forest user groups (FUGs).

The decline in deforestation rates from 2008-2015 appears to be explained by better forest protection from indigenous forest-based livelihoods (Hylander et al, 2013, Tadesse et al, 2014), the result of better protection of forests by FUGs under the PFM being implemented in the study area since 1996. The 1973 land use land cover map Fig. 4) illustrates (that most of the land are primarily covered by forest land which accounted to 2711.52 ha $(79.28 \%)$ of the total study area.

Agricultural land (AL) this category of land cover included areas of land ploughed/prepared for growing rainfed or irrigated. AL cover constituted $17.25 \%$ of the total area of the study area in 1973. AL cover extent and its proportional share in the years 1984, 1998, 2008, 2015 were, $18.35 \%, 21.50 \%, 23.70 \%$ and $23.53 \%$ respectively. AL have shown increasing trends from 1973 to 2008 (Table 4). However, in 2015 this land cover has slightly declined to 23.53 from $23.70 \%$ in 2008. Teff, wheat and barley are the most cultivated crops in the study area.

\section{Land Use Land Cover Change Matrix}

The land use change (LUC) matrices illustrate the changes in magnitude and directions in LUCC classes.

\section{Land Use Land Cover Change Matrix1973-1984}

During this period the significant area of the forest land cover has converted into different land use types such as rural settlements (0.52 ha), agricultural land (100.5 ha), BL (7.3 ha) and shrubland (200.52 ha) and the highest portion of the forest land has converted to shrubland. This has resulted in the decline of the forest land cover area. There has been a considerable increase in the agricultural land area (590.04 ha) during 1973 to (627.66 ha) in 1984, though a small portion of its cover was changed into bare land and road (92.6 ha) as it has shown from (Table 6). 
Siraj M., Zhang K., Moges K.: Retrospective Analysis of Land Use Land Cover Dynamics Using GIS and Remote sensing in Central Highlands of Ethiopia

Table 6: LUCC Matrix of 1973 -1984 (ha)

\begin{tabular}{clllllll}
\hline & $\mathbf{1 9 8 4}$ & & & & & \multicolumn{1}{c}{$\begin{array}{c}1973 \\
\text { Total }\end{array}$} \\
\cline { 2 - 7 } & LUCC & RSL & AL & BL & ShL & FL & 0.36 \\
\cline { 2 - 6 } & RSL & 0.36 & 0 & 0 & 0 & 0 & 590.04 \\
& AL & & 497.44 & 92.6 & 0 & 0 & 0 \\
& Bl & 0 & 0 & 0 & 0 & 0 & 118.44 \\
& ShL & 0.59 & 29.71 & 4.11 & 84.03 & 0 & 2711.52 \\
& FL & 0.52 & 100.51 & 7.3 & 205.2 & 2398 & 3420.36 \\
\hline
\end{tabular}

*Al=Agricultural land, $\mathrm{BL}=$ bare land and road, $\mathrm{FL}=$ Forest land, $\mathrm{RSl}=$ Rural Settlements, $\mathrm{Sh}=$ Shrub lands

Land Use Land Cover Change Matrix of 1984 to 1998

During this period the largest portion of forest land area has converted into the shrubland 328. 55ha as evidenced in (Table 7). However, the area of forest land converted to agricultural land is lower than the period (1973-1984) by 40.39 ha. During the year (1984-19998) agricultural land has increased considerably by 109.84 ha, though some portion of its cover was changed into rural settlements ( 0.39 ha) and bare land and road (29.34 ha). During this period 61.7 ha of shrubland, bare land 15.75 ha and 60.12 ha of forest land has converted into agricultural land.

Table 7: LUCC Matrix of 1984 -1998 (ha)

\begin{tabular}{clllllll}
\hline & $\mathbf{1 9 9 8}$ & & & & & & $\begin{array}{c}1984 \\
\text { Total }\end{array}$ \\
\cline { 2 - 7 } & LUCC & RSL & AL & BL & ShL & FL & 1.47 \\
& RSL & 1.47 & 0 & 0 & 0 & 0 & 627.66 \\
& AL & 0.39 & 597.93 & 29.34 & 0 & 0 & 104.01 \\
& BL & 0 & 15.75 & 85.33 & 2.93 & 0 & 289.26 \\
1998 Total & ShL & 0 & 61.7 & 1.17 & 226.39 & 0 & 2397.96 \\
\hline
\end{tabular}

*Al=Agricultural land, $\mathrm{BL}=$ bare land and road, $\mathrm{FL}=$ Forest land, $\mathrm{RSl}=$ Rural Settlements, $\mathrm{Sh}=$ Shrub lands

\section{LUCC Matrix of 1998-2008}

The main processes of land use change were the conversion between forest land, agricultural land, rural settlements and bare land and road as evident from (Table 8), the area of agricultural land has been significantly increased to 810.48 ha during this period, although some portion of its extent was converted to rural settlements (25.32 ha) and bare land (17.88 ha). As shown in the table (table 8), the ultimate main contributors to the significant increment of the agricultural land area were shrubland (49.91 ha), bare land (42.15 ha) and forest land (26.12 ha). During this period (214.23 ha) of forest land has converted to other land use types with the highest share was taken by shrubland (159.98 ha), followed by bare land and road (27.8 ha), and agricultural land (26. $12 \mathrm{ha}$ ). 
The forest land area converted into the other land types with an annual rate of 19.4754 ha during the period 1998-2008.

Table 8: LUCC Matrix of 1998 - 2008(ha)

\begin{tabular}{|c|c|c|c|c|c|c|c|}
\hline & \multirow[b]{2}{*}{ LUCC } & \multicolumn{3}{|c|}{2008} & \multirow[b]{2}{*}{$\mathrm{ShL}$} & \multirow[b]{2}{*}{ FL } & \multirow{2}{*}{$\begin{array}{c}1998 \\
\text { Total } \\
\end{array}$} \\
\hline & & RSL & $\mathrm{AL}$ & BL & & & \\
\hline \multirow{6}{*}{$\stackrel{\circ}{\sigma}$} & RSL & 1.86 & 0 & 0 & 0 & 0 & 1.86 \\
\hline & $\mathrm{AL}$ & 25.32 & 692.3 & 17.88 & 0 & 0 & 735.5 \\
\hline & BL & 0 & 42.15 & 123.75 & 0 & 0 & 165.9 \\
\hline & $\mathrm{ShL}$ & 0 & 49.91 & 11.2 & 493.43 & 3.33 & 557.87 \\
\hline & FL & 0 & 26.12 & 27.8 & 159.98 & 1745 & 1959.23 \\
\hline & Total & 27.18 & 810.48 & 180.63 & 653.41 & 1749 & 3420.36 \\
\hline
\end{tabular}

*Al=Agricultural land, $\mathrm{BL}=$ bare land and road, $\mathrm{FL}=$ Forest land, $\mathrm{RSl}=$ Rural Settlements, $\mathrm{Sh}=$ Shrub lands

\section{LUCC Matrix of 2008 - 2015(ha)}

During this period like the other three periods, forest has converted to other land use types, however, the extent of the forest land area converted to other land types is lower than the other three periods. This implies deforestation has decreased compared to the other three periods as a result of the new forest management practices. During this period shrubland area has lost about 189.18 ha to the forest but balanced by gaining 61.52 ha from bare land and 67.7 ha from forest land. The extent of shrubland has been decreased by 102.7 ha from 653.41 ha in 2008 to 550.71 ha in 2015. The extent of forest land area coverage has increased by 40.72 ha during this period from1748.66 ha in 2008 to1789.38 ha in 2015 .

Table 9: LUCC Matrix of 2008 to 2015 (ha)

\begin{tabular}{|c|c|c|c|c|c|c|c|}
\hline \multicolumn{7}{|c|}{2015} & \multirow[t]{2}{*}{2008 Total } \\
\hline & LUCC & RSL & $\mathrm{AL}$ & $\mathrm{BL}$ & ShL & FL & \\
\hline \multirow{5}{*}{$\stackrel{\infty}{\stackrel{\overbrace{}}{్}}$} & RSL & 27.18 & 0 & 0 & 0 & 0 & 27.18 \\
\hline & $\mathrm{AL}$ & 5.34 & 793.48 & 11.66 & 0 & 0 & 810.48 \\
\hline & BL & 5.38 & 2.84 & 110.89 & 61.52 & 0 & 180.63 \\
\hline & ShL & 10.89 & 5.3 & 26.55 & 421.5 & 189.18 & 653.41 \\
\hline & FL & 1.64 & 3.25 & 75.87 & 67.7 & $\begin{array}{l}1600.2 \\
1789.3\end{array}$ & 1748.66 \\
\hline 2015 Total & & 50.43 & 804.87 & 224.97 & 550.7 & 8 & 3420.36 \\
\hline
\end{tabular}

*Al=Agriculutral land, $\mathrm{BL}=$ bare land and road, $\mathrm{FL}=$ Forest land, $\mathrm{RSl}=$ Rural Settlements, $\mathrm{Sh}=$ Shrub lands 
Siraj M., Zhang K., Moges K.: Retrospective Analysis of Land Use Land Cover Dynamics Using GIS and Remote sensing in Central Highlands of Ethiopia

\section{Analysis of LUCC Dynamics (Rate and Pattern) 1973-2015}

During 1973-2015 periods all land use types have increased agricultural land (36.4\%), bare land and road (214.8\%), shrubland (23908.3\%) except the forest land area. During this period the forest land has lost 922.5 ha (34\%) of its original area (Fig. 4.2.3). The highest amount of forest 438.73 ha has lost during the period 1984- 1998 (Table 4.2.3.1), especially the change in government in 1991 has exposed the forest area for illegal harvesting of timber and encroachments. However, the forestland has increased during 2008-2005 period by $2.3 \%$, this is due to the change in management practices of the natural resources. The forest LUCC type has lost the most while shrubland gained at the most magnitude. This significantly may constrain the capacity of forests to provide ecosystem goods and services to the local communities (Table 10 see in appendix).

Regarding LUCC rate of change, agricultural land has been remarkably increased annually by 3.14 ha 7.14 ha, 6.82 ha during the period, 1973-1984; 1984-1998, 1998-2008 respectively, however during the 2008-2015 period, the agricultural land has declined annually by 0.70 ha. However, other land types bare land and road, rural settlement and shrubland have increased during the study period (1973-2015). In contrast, the annual rate of forest land area depletion was substantially increased throughout the periods except in 2008-2015. Generally, during the study period 1973-2015, the forest area has converted into other land use type area annually by 21.45 ha (Table 11 see in appendix and Fig. 5). During the study period, 1973- 2015 bare land has increased from zero percent in 1973 to $214.8 \%$, due to road construction, that dissected the forest and goes to Jeldu and Ginde Beret. During the study period 1973-2015 the shrubland has increased by $365 \%$ from its original cover while rural settlements have increased by $13908 \%$ which is the highest change.

Fig. 5: Rate of Changes in LUCC Classes in ha (1973-2015)

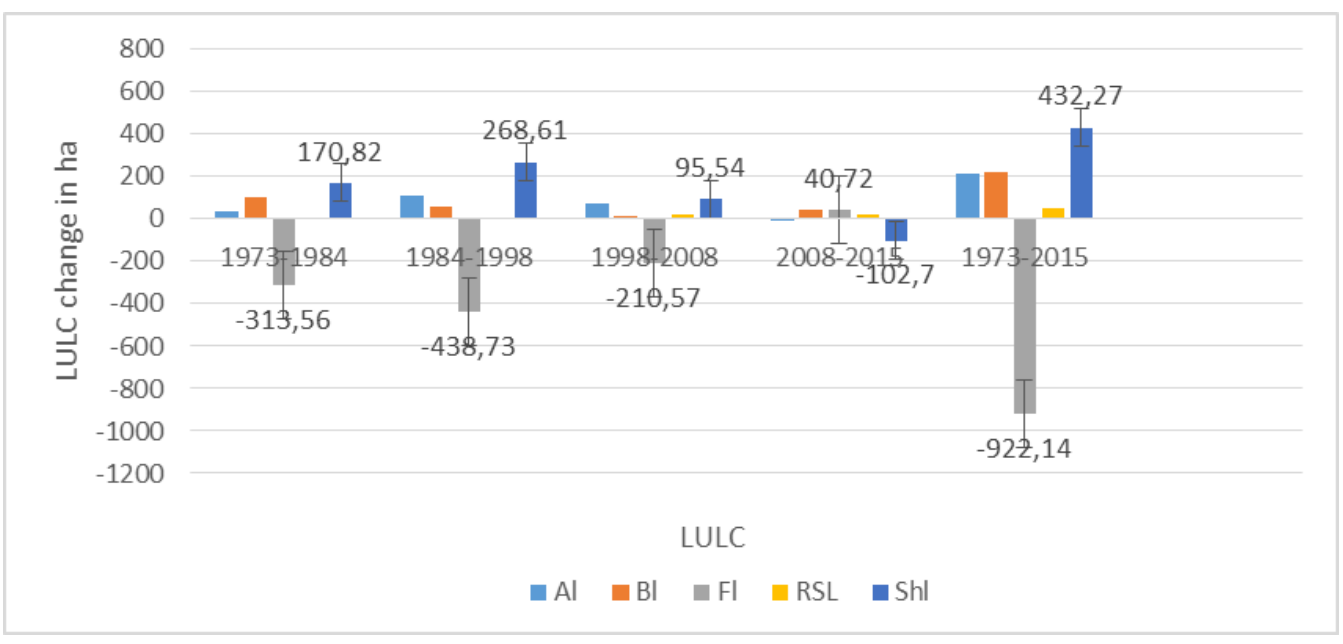




\section{Local Perceptions on Forest Cover Change}

The results of the findings in the study area revealed 17 proximate and underlying drivers of deforestation. The most commonly reported drivers in the study area were agriculture, rural settlements, population growth, insecurity of the tenure and rights over the land, timber production and fuel wood collection.The majority of interviewed households responded that the observed decrease in forest land due to expansion of smallholder agricultural land $(88.89 \%)$ and rural settlement (88.44\%) respectively(Fig. 6.).

\section{Fig. 6. Direct causes of Deforestation}

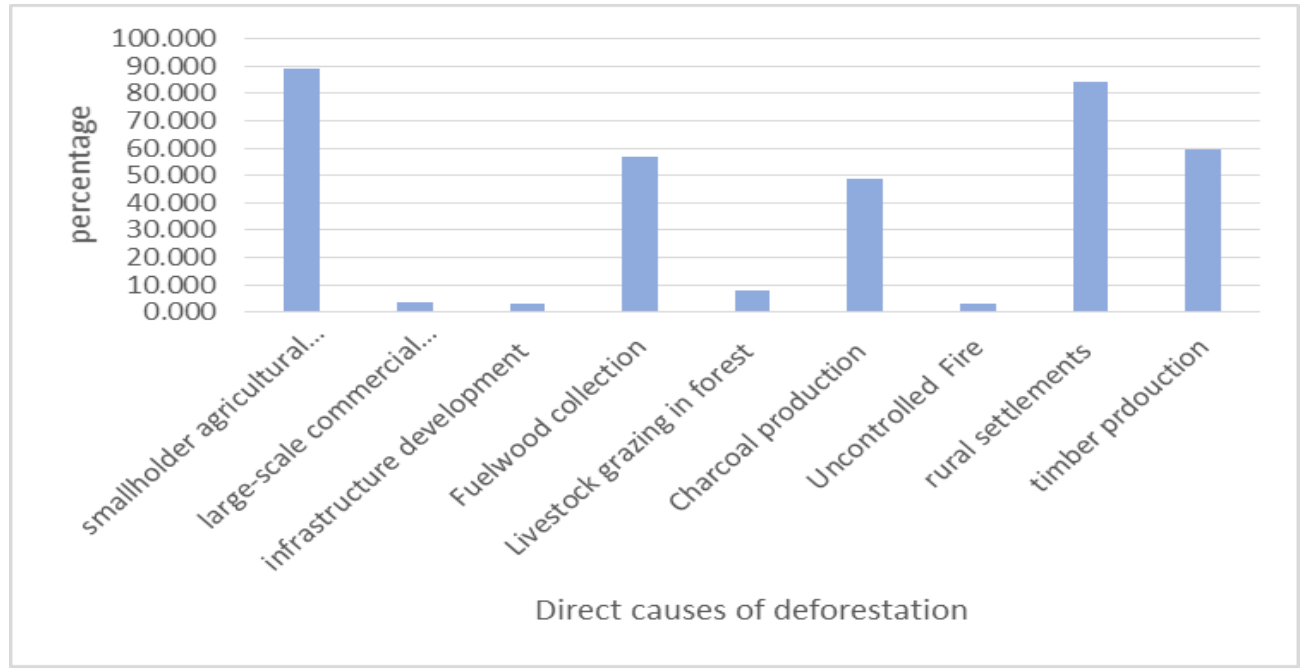

Ethiopia's rapidly growing population relies on a fragile natural resource base for livelihood security (Yirgu et al, 2013). The result of this study indicated that landscape changes in Chilimo-Gaji forest have occurred over the last 43 years. According to the UN report 2015 report,Ethiopia is ranked $5^{\text {th }}$ as one of the nine counties in which the half of the population growth is expected to be concentated during the period 2015-2050,: India, Nigeria, Pakistan, Democratic Republic of the Congo, Ethiopia, United Republic of Tanzania, United States of America, Indonesia and Uganda, listed according to the size of their contribution to the total growth. The recent data for Ethiopia population projections is indicated in (Fig. 7.). 
Fig. 7: Underlying causes of deforestation

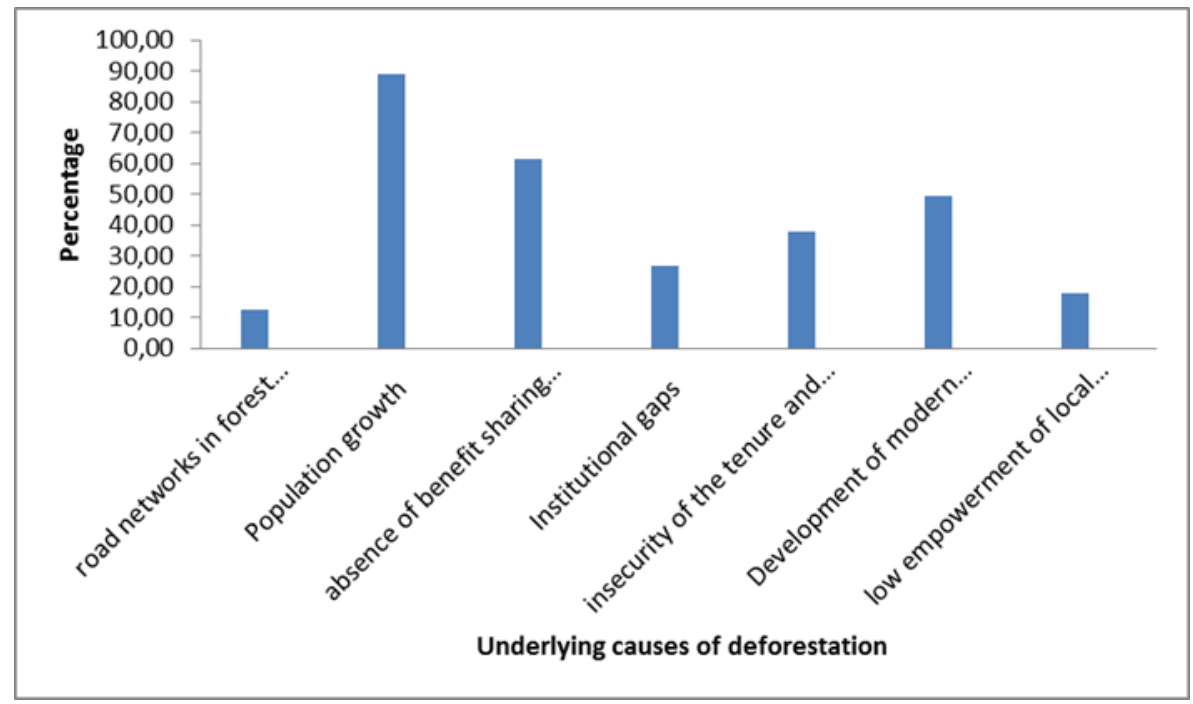

Ethiopia is among the top three countries in Africa along with Nigeria and South as the largest user of traditional fuels for household energy in the world, with $96 \%$ of the population dependent on traditional fuel (e.g. firewood, charcoal, agricultural residue and animal waste) to meet their energy needs. Most of the firewood is used for baking Injera (one kind of traditional food like soft pancake and it is the most popular food for Ethiopia) baking is particularly demanding as it consumed $50 \%$ of all household cooking fuels. Collection of the firewood from the forest by cutting the living trees is another problem that has been seen Chilimo Gaji forest.

The forest degradation and deforestation in Ethiopia is closely linked to the ongoing population growth. More people generally lead to an increasing demand on land for living and for agricultural production. These changes included expansion of agricultural areas, rural settlements and decline of forest cover resulting fragmentation of the area forests. Many forest fragments occurred at higher elevations (in hill-slopes) that are less suitable for cultivation in agreement with (Tadesse et al, 2014). Population growth $(88.89 \%)$ and the insecurity of the tenure and rights over the land $(74.07 \%)$ were the major underlining causes of deforestation. The demand land for agriculture and settlement for increasing population and expansion of agriculture led to clearing of the forest in the study area. The land cover changes that have been recognized in the study area had shown continuous expansion of agricultural land in order to meet the increasing food demands of the growing population.

\section{CONCLUSION AND RECOMMENDATIONS}

The assessment of forest information over time enables the comprehensive monitoring of forest resources (Boyd \& Danson, 2005) and remote sensing plays a crucial role in measuring forest condition and their extent. The result of this study indicated that there were significant LUCC changes and landscape change trends in the years covered by the study over the last 
43 years and five classes LUCC have been identified, namely, shrubland, rural settlement, bare land and road, forest land and agricultural land. The most commonly reported drivers of deforestation in the study area were the expansion of agricultural land, rural settlements, population growth, insecurity of the tenure and rights over the land, timber production and fuel wood collection. This was related to the increasing demand for agricultural land and settlement land for increasing human population, problems related to land policy and lack of benefit sharing mechanisms. Agriculture, shrub, rural settlements and bare land and road were expanded at the expense of forest. This has resulted in a significant decrease in the forest LUCC classes. The continuation of land use/land cover changes combined with increasing demand for resources have seriously affected the flora, fauna, and microbial diversity of the Chilimo Gaji forest.

Human land use, particularly over the past 43 years, has changed the trend of land cover and ecosystems more rapidly and broadly. This has occurred as a result of rapidly growing demand on natural resources. The forest land cover type has lost much compared to all other land cover types followed by significant magnitude of loss for shrubland. However, deforestation rates has declined from 2008-2015 as a result of introduction of participatory forest management schemes (1996) involving the local community in management and sharing of the benefit obtained from the management. In conclusion, rapid human population growth has underpinned the expansion of agricultural land and rural settlements in the study area at the expense of forest land. The study indicated that 922.14 ha $(26.96 \%)$ of forest area have been changed into other land cover types such as agriculture and settlement within the time period under consideration (1973-2015) in Chilimo Gaji.

Urgent strategic and practical measures involving integrated land use planning and management and addressing key environmental, socio-economic and socio-cultural drivers of land use and land cover change in the study area are recommended for promoting sustainable natural resources management in the study area. More importantly, strengthening the established forest use groups in the study area and sharing their best practices in other parts of Ethiopia is the best wisdom to improve forest resources management in current and future Ethiopia.

\section{REFERENCES}

Agarwal, S., Puri, K., Areendran, G., Raj, K., Govil, H., Mazumdar, S., \&Munsi, M (2010). Forest Change analysis of Jim Corbett National Park, Uttarakhand: A remote sensing and GIS approach. ESRI India User Conference.

Agrawal, A. \& Angelsen, A. (2009). Using community forest management to achieve REDD+ goals. In A. Angelsen, ed., Realising REDD+: national strategy and policy options (pp. 1-10). Bogor, Center for International Forestry Research.

Alemayehu, F., Taha, N., Nyssen, J., Girma, A., Zenebe, A., Behailu, M. \&Poesen, J. (2009). The impacts of watershed management on land use and land cover dynamics in Eastern Tigray (Ethiopia). Resources, Conservation and Recycling, 53(4), pp. 192-198.

Alemu, B. (2015). The Effect of Land Use Land Cover Change on Land Degradation in the Highlands of Ethiopia. Journal of Environment and Earth Science. 5 (1).

Amare, B. (2007). Landscape Transformation and Opportunities for Sustainable Land Management along the Escarpments of Wello, Ethiopia. PhD Thesis, Bern University, Bern.

Ayele, H. (2011). Land use/land cover change and impact of Jatropha on soil fertility: the case of Mieso and Bati Districts, Ethiopia. M. Sc. thesis. 
Siraj M., Zhang K., Moges K.: Retrospective Analysis of Land Use Land Cover Dynamics Using GIS and Remote sensing in Central Highlands of Ethiopia

Bewket, W. (2002). Land cover dynamics since the 1950s in Chemoga watershed, Blue NileBasin, Ethiopia. Mountain Research and Development, 22(3), pp. 263-269.

Biru, M. K., \& Debay, A. B. (2015). Multitemporal Land Use Land Cover Change and Dynamics of Blue Nile Basin by Using GIS and Remote Sensing Techniques, North-Western Ethiopia. International Journal of Environmental Sciences. 4 (2), pp. 81-88.

Boyd, D.S. \& Danson, F.M., (2005). Satellite remote sensing of forest resources: three decades of research development. Progress in Physical Geography, 29(1), pp.1-26.

Chowdhury, R. R. (2006). Driving forces of tropical deforestation: The role of remote sensing and spatial models. Singapore Journal of Tropical Geography, 27(1), pp. 82-101.

Desclée, B., Bogaert, P., \& Defourny, P. (2006). Forest change detection by statistical object-based method. Remote Sensing of Environment, 102(1), pp. 1-11.

Du, X., Jin, X., Yang, X., Yang, X., \& Zhou, Y. (2014). Spatial pattern of land use change and its driving force in Jiangsu province. International journal of environmental research and public health, 11(3), pp. 3215-3232.

Dugo, G. S. (2009). The structure and regeration status of tree and shrub species of chilimo forest-ecological sustainability Indicators for participatory forest management (PFM) in Oromia, Ethiopia.

Foody, G. M. (2002). Status of land cover classification accuracy assessment. Remote sensing of environment, 80(1), pp. 185-201.

Garede, N. M., \& Minale, A. S. (2014). Land Use/Cover Dynamics in Ribb Watershed, North Western Ethiopia. J. Nat. Sci. Res, 4(9), p.16.

Geist, H., Lambent, E. (2001). What drives tropical deforestation? A meta-analysis of proximate and underlying causes of deforestation based on subnational case study evidence. Land-use and land-cover change (LUCC) project, International Geosphere- Biosphere Programme (IGBP). LUCC Report Series: 4.

Geist, H. (1999). Exploring the entry points for political ecology in the international research agenda on global environmental change. Zeitschriftfür Wirtschaftsgeographie, 43(1), pp. 158-168.

Gessesse, D. \& Kleman, J. (2007). Pattern and Magnitude of Deforestation in the South Central Rift Valley Region of Ethiopia. Mountain Research and Development. 27: pp. 162-168.

Gillanders, S. N., Coops, N. C., Wulder, M. A., Gergel, S. E., \& Nelson, T. (2008). Multitemporal remote sensing of landscape dynamics and pattern change: describing natural and anthropogenic trends. Progress in Physical Geography, 32(5), pp. 503-528.

Giri, C., Pengra, B., Zhu, Z., Singh, A., \&Tieszen, L. L. (2007). Monitoring mangrove forest dynamics of the Sundarbans in Bangladesh and India using multi-temporal satellite data from 1973 to 2000. Estuarine, Coastal and Shelf Science, 73(1), pp. 91-100.

Golmehr, E. (2009). Current Application of Remote Sensing Techniques in Land Use Mapping: A Case Study of Northern Parts of Kolhapur District, India. Journal of Applied Sciences and Environmental Management, 13(4).

Haregeweyn, N., Fikadu, G., Tsunekawa, A., Tsubo, M., \& Meshesha, D. T. (2012). The dynamics of urban expansion and its impacts on land use/land cover change and small-scale farmers living near the urban fringe: A case study of Bahir Dar, Ethiopia. Landscape and urban planning, 106(2), pp. 149-157. 
IGU. (1998). Land use/cover change. Land Use Policy 15 2: pp. 165-166.

Ismail, M. H., \& Jusoff, K. (2008). Satellite data classification accuracy assessment based from reference dataset. International Journal of Computer and Information Science and Engineering, 2(2), pp. 96-102.

Jahjah, M., \&Ulivieri, C. (2004). GIS and RS integration: application of geostatistical techniques and environmental changes in the coastal zone in Kenya. In Remote Sensing (pp. 14-25). International Society for Optics and Photonics.

Keno, B. \& Suryabhagavan, K. V. (2014). Multitemporal remote sensing of landscape dynamics and pattern change in Dire district, southern Ethiopia Journal of Geomatics 8 (2).

Lambin, E. F., Geist, H. J., \& Lepers, E. (2003). Dynamics of land-use and land-cover change in tropical regions. Annual review of environment and resources, 28(1), pp. 205-241. Lu, D., Mausel, P., Brondizio, E., Moran, E. (2004). Change detection techniques. Int. J. Remote Sensing 25(12): pp. 2365-2407.

Mekonnen, M., Sewunet, T., Gebeyehu, M., Azene, B., \& Melesse, A. M. (2016). GIS and Remote Sensing-Based Forest Resource Assessment, Quantification, and Mapping in Amhara Region, Ethiopia. In Landscape Dynamics, Soils and Hydrological Processes in Varied Climates (pp. 9-29). Springer International Publishing.

Minale, A. S. (2013). Retrospective analysis of land cover and use dynamics in GilgelAbbay Watershed by using GIS and remote sensing techniques, Northwestern Ethiopia. International Journal of Geosciences, 4(07), p. 1003.

Monserud, Robert A. (2003): Evaluating forest models in a SFM context. Forest Biometry, Modelling and Information Sciences 1(1). Pp. 35-47.

Morshed, A. (2002). Land use change dynamics: A dynamic spatial simulation (Doctoral dissertation, PhD Thesis).

Pielke, R. A., Marland, G., Betts, R. A., Chase, T. N., Eastman, J. L., Niles, J. O., \& Running, S. W. (2002). The influence of land-use change and landscape dynamics on the climate system: relevance to climate-change policy beyond the radiative effect of greenhouse gases. Philosophical Transactions of the Royal Society of London A: Mathematical, Physical and Engineering Sciences, 360(1797), pp. 1705-1719.

Pomeroy, D., Tukahirwa, J., Mugisha, S., Nanyunja, R., Namaganda, M. and Chelimo N (2003) Linkages between Change in Land Use, Land Degradation and Biodiversity in SW Uganda. Retrieved August 3, 2003 from www.lucideastafrica.org

Ramankutty, N.; Foley, J.A. (1998). Characterizing patterns of global land use: An analysis of global croplands data. Glob. Biogeochem. Cycles 1998, 12, pp. 667-685.

Running, T., \& Bauer, M. E. (1996). Change detection in forest ecosystems with remote sensing digital imagery. Remote sensing reviews, 13, pp. 207-234.

Skole, D., Justice, C., Townshend, J., \& Janetos, A. (1997). A land cover change monitoring program: strategies for equitable development, for forests, for people. New York

Soromessa, T., \& Kelbessa, E. (2013). Diversity and endemicity of Chilimo forest, central Ethiopia. Bioscience Discovery, 4(1), pp. 1-4.

Thapa, R., \& Murayama, Y., (2009). Urban Mapping, Accuracy, \& Image Classification: A Comparison of Multiple Approaches in Tsukuba City, Japan, Applied Geography, 29, pp.135-144. 
Siraj M., Zhang K., Moges K.: Retrospective Analysis of Land Use Land Cover Dynamics Using GIS and Remote sensing in Central Highlands of Ethiopia

Turner, M. G., Wear, D. N., \&Flamm, R. O. (1996). Land ownership and land-cover change in the southern Appalachian highlands and the Olympic peninsula. Ecological applications, 6(4), pp. 1150-1172.

Vashum, K. T., \& Jayakumar, S. (2012). Methods to estimate above-ground biomass and carbon stock in natural forests-a review. J. Ecosyst. Ecogr, 2(4), pp. 1-7.

Weng, Q. (2002). Land use change analysis in the Zhujiang Delta of China using satellite remote sensing, GIS and stochastic modelling. Journal of environmental management, 64(3), pp. 273-284.

Woldemariam, T.G. (1998). Diversity of Woody Plants and Avifauna in a Dry Afromontane Forest: on the Central Plateau of Ethiopia MSc Thesis Swedish University of Agricultural Sciences, Skinnskatteberg, Sweden.

Zerga, B. (2016). Land Resource, Uses, and Ownership in Ethiopia: Past, Present and Future. International Journal of Scientific Research Engineering Technology 2 (1).

Zornoza, R., Acosta, J. A., Bastida, F., Domínguez, S. G., Toledo, D. M., \& Faz, A. (2015). Identification of sensitive indicators to assess the interrelationship between soil quality, management practices and human health. Soil, 1(1), p. 173. 

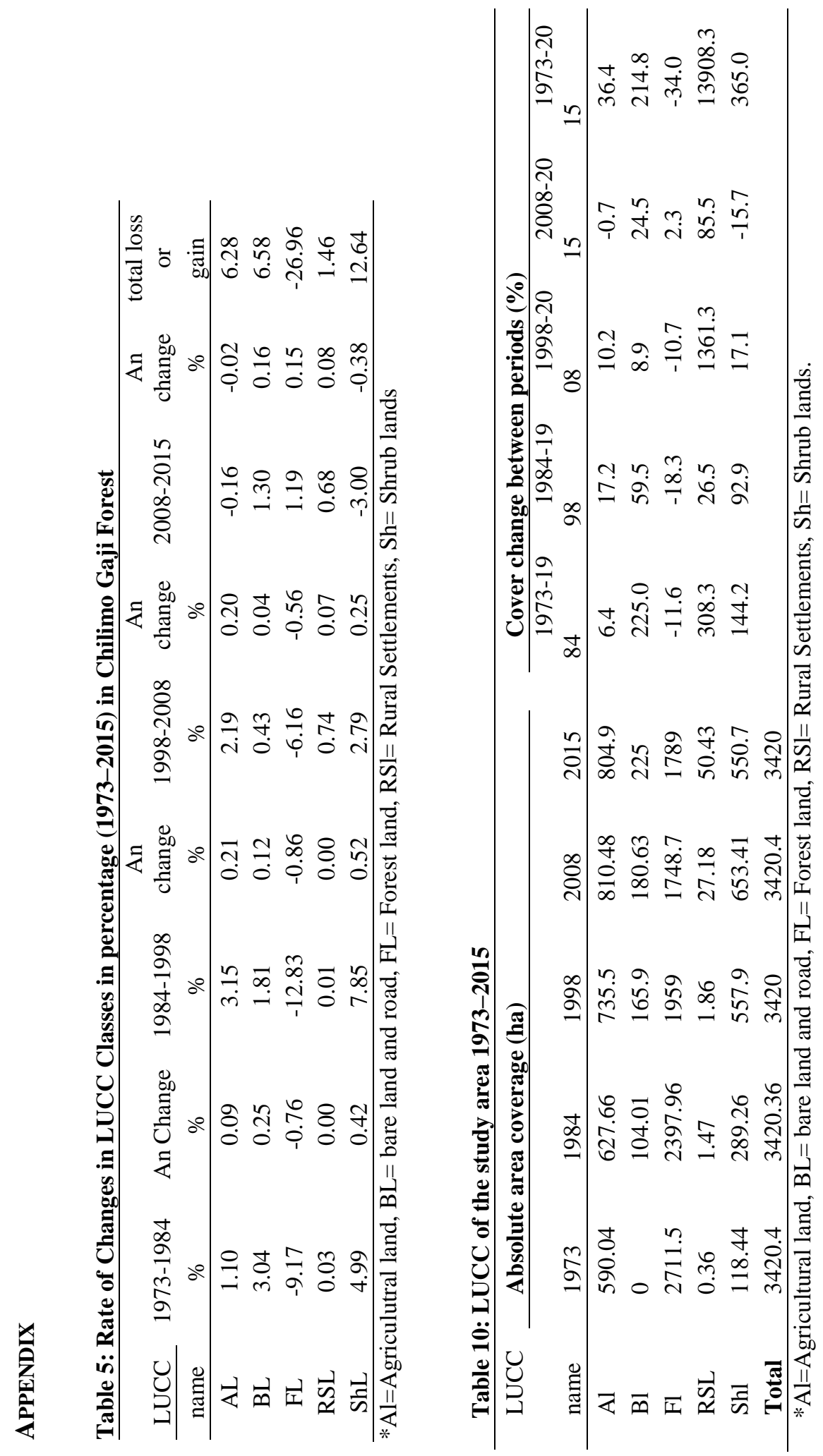

$\bar{n}$ 


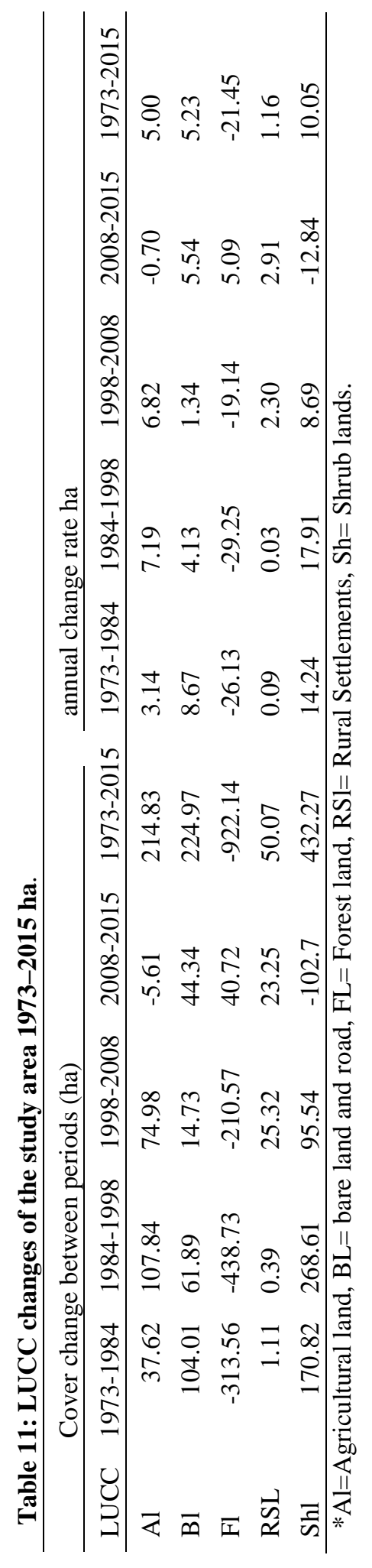

